\title{
Regadenoson is a better myocardial vasodilator than dipyridamole in normal volunteers, but the data is less compelling in patients
}

\author{
Sujethra Vasu*, W Patricia Bandettini, Li-Yueh Hsu, Peter Kellman, Marcus Y Chen, Joel Wilson, Steve Leung, \\ Sujata M Shanbhag, O Julian Booker, Christine Mancini, Jennifer Henry, Tracy Lowrey, Andrew E Arai
}

From 2011 SCMR/Euro CMR Joint Scientific Sessions

Nice, France. 3-6 February 2011

\section{Introduction}

Regadenoson is a selective Adenosine-2A receptor agonist and is used for myocardial perfusion imaging. Dipyridamole causes indirect vasodilation by inhibiting cellular reuptake of adenosine. The purpose of this study was to assess whether regadenoson is a better coronary vasodilator than dipyridamole in normal volunteers and in patients.

\section{Hypothesis}

Regadenoson causes a $25 \%$ higher myocardial blood flow (MBF) than dipyridamole.

\section{Methods}

Forty patients with normal coronaries/minimal stenosis on coronary CT angiography had also undergone vasodilator stress MR (regadenoson $n=20$, dipyridamole $\mathrm{n}=20$ ). Seventeen healthy normal volunteers with Framingham score less than $1 \%$ underwent vasodilator stress testing with regadenoson and dipyridamole in two separate studies using a SSFP sequence. Stress imaging was done 70 seconds post regadenoson injection and 4 minutes after completing the dipyridamole infusion. All patients and volunteers received aminophylline after stress imaging. Rest imaging was done 20 minutes later. $\mathrm{MBF}$ in $\mathrm{ml} / \mathrm{min} / \mathrm{g}$ and Myocardial perfusion reserve (MPR) were quantified using a fully quantitative model constrained deconvolution (MCD).

\section{Results}

Normal volunteers had higher stress MBF (mean \pm standard error) with regadenoson than dipyridamole (3.72 \pm

National Institutes of Health, Bethesda, MD, USA
0.18 vs. $2.90 \pm 0.17, \mathrm{p}=0.001$ ) and higher MPR with regadenoson $(2.75 \pm 0.19$ vs. $2.27 \pm 0.14, \mathrm{p}=.03)$. In patients, higher MPR was found with regadenoson $(2.45 \pm 0.12$, vs. $2.12 \pm .10, \mathrm{p}=.04)$. Stress MBF trended higher in patients with regadenoson than dipyridamole (2.78 \pm 0.14 vs. $2.54 \pm 0.13, \mathrm{p}=0.22$ ). No difference in the resting blood flow between regadenoson and dipyridamole was found in normal volunteers $(1.44 \pm 0.19$ vs. $1.31 \pm 0.07$, $\mathrm{p}=.07)$ and in patients $(1.14 \pm 0.03$ vs. $1.24 \pm 0.08, \mathrm{p}=.26)$ respectively. Figures 1-3.

\section{Conclusions}

Regadenoson is a better coronary vasodilator than Dipyridamole in normal volunteers with higher MBF and MPR. However in patients, the small sample size in this study limits the sensitivity to detect differences in stress perfusion.

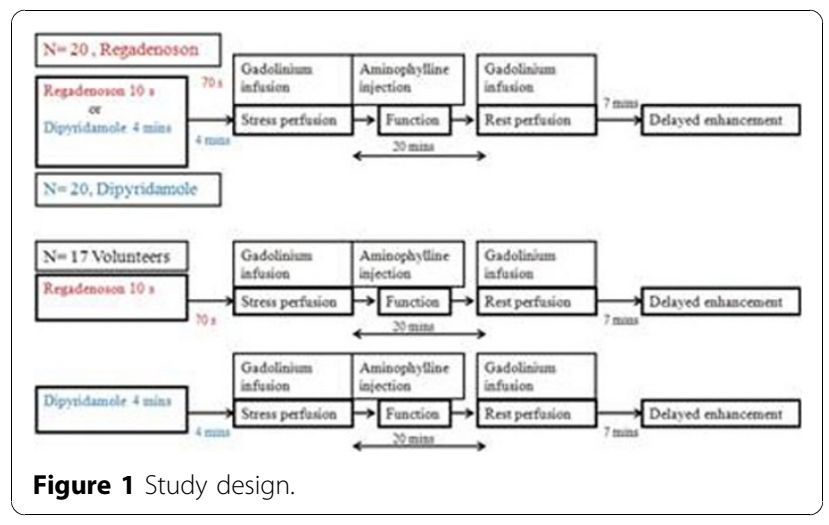

(c) 2011 Vasu et al; licensee BioMed Central Ltd. This is an open access article distributed under the terms of the Creative Commons 

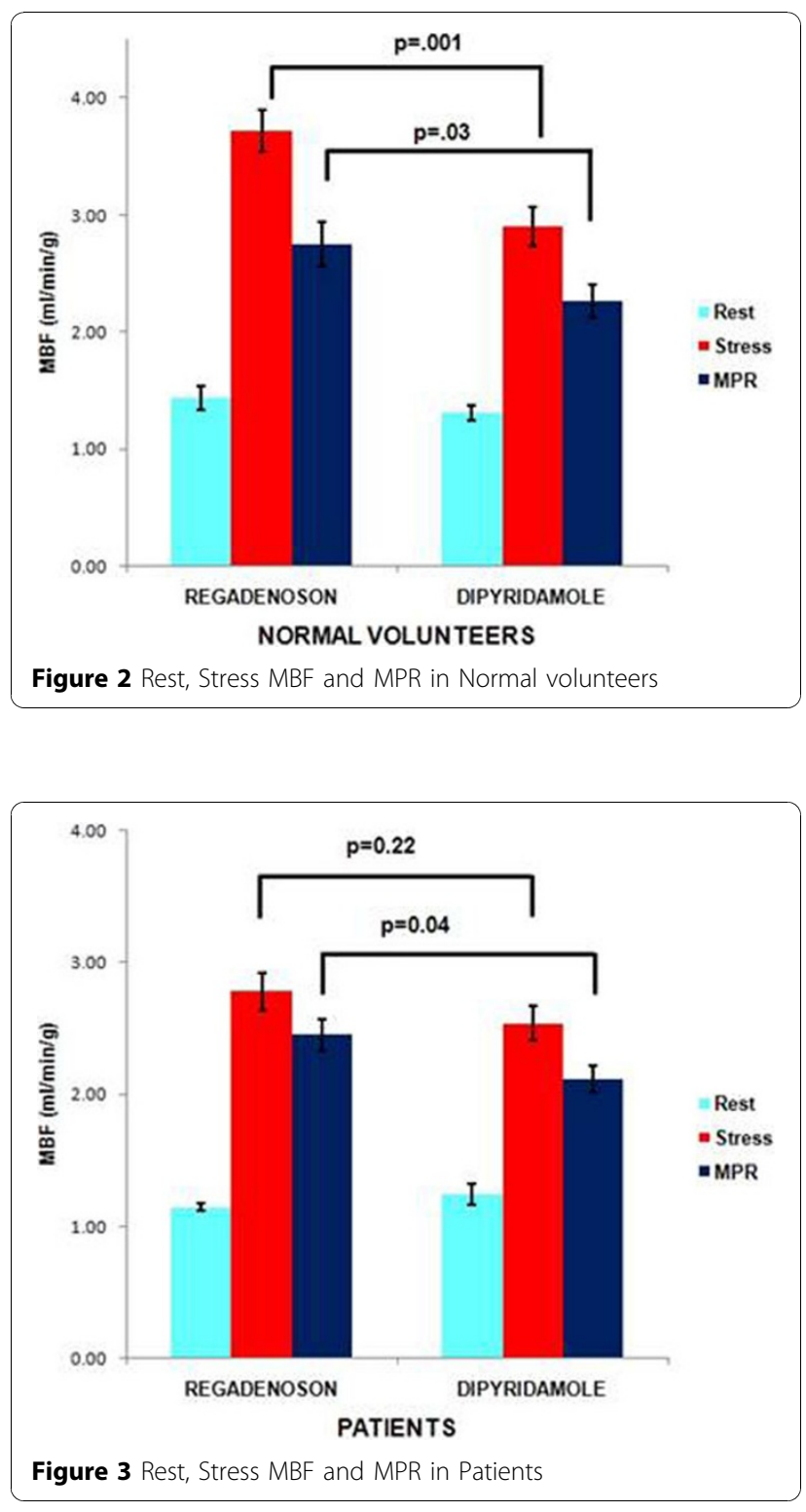

Published: 2 February 2011

doi:10.1186/1532-429X-13-S1-P124

Cite this article as: Vasu et al:: Regadenoson is a better myocardial vasodilator than dipyridamole in normal volunteers, but the data is less compelling in patients. Journal of Cardiovascular Magnetic Resonance 2011 13(Suppl 1):P124.

\section{Submit your next manuscript to BioMed Central} and take full advantage of:

- Convenient online submission

- Thorough peer review

- No space constraints or color figure charges

- Immediate publication on acceptance

- Inclusion in PubMed, CAS, Scopus and Google Scholar

- Research which is freely available for redistribution

Submit your manuscript at www.biomedcentral.com/submit
C Biomed Central 